\title{
Resepsi Audiens Terhadap Transgender dalam Film Dokumenter Bulu Mata
}

\author{
Kevi Restu Pradhita ${ }^{1}$ dan Fajar Junaedii ${ }^{*}$ \\ Universitas Muhammadiyah Yogyakarta \\ Email: kevirestupradhita@gmail.com ${ }^{1}$ dan fajarjun@gmail.com ${ }^{2 *}$ \\ *corresponding author
}

Keywords:

film, transgender, gender identity, reception analysis.

\section{Kata Kunci:}

film, transgender, identitas gender, analisis resepsi.

\begin{abstract}
Film is one of the mass communication media that is effective in disseminating information that aims to convey messages to the public. One documentary film entitled Bulu Mata tells how transgender life is in a region that still upholds Islamic law. Transgender is a person who has a gender identity that is different from his original gender. In Indonesia, transgender is still a taboo thing in society and is considered a negative behavior. This study aims to find out how the audience's reception of transgender in a documentary entitled Bulu Mata. The theory used in this research is the theory of audience reception from Stuart Hall. This study uses a qualitative descriptive approach method and data collection techniques using in-depth interview method. In this study, it was successful to show audience receptions in interpreting Bulu Mata films very differently. Informants with backgrounds who are interested in gender issues are in a dominant position, informants with backgrounds that follow Kine's film organization are in negotiated positions, and informants who follow Rohis organizations are in oppositional positions.
\end{abstract}

\begin{abstract}
ABSTRAK
Film merupakan salah satu media komunikasi massa yang efektif dalam penyebaran informasi yang bertujuan untuk menyampaikan pesan kepada khalayak. Salah satu film dokumenter yang berjudul Bulu Mata menceritakan bagaimana kehidupan transgender yang berada di wilayah yang masih menjunjung tinggi syariat Islam. Transgender merupakan seorang yang memiliki identitas gender yang berbeda dengan gender aslinya saat lahir. Di Indonesia transgender masih menjadi hal yang tabu di masyarakat dan dianggap suatu perilaku yang negatif. Penelitian ini bertujuan untuk mengetahui bagaimana resepsi audiens terhadap transgender dalam film dokumenter yang berjudul Bulu Mata. Teori yang digunakan pada penelitian ini adalah teori Resepsi Audiens dari Stuart Hall. Penelitian ini menggunakan metode pendekatan deskriptif kualitatif serta teknik pengumpulan data menggunakan metode wawancara mendalam (indepth interview). Pada penelitian ini berhasil menunjukan resepsi khalayak dalam memaknai film Bulu Mata amat berbedabeda. Informan dengan latar belakang yang tertarik dengan isu gender berada pada posisi dominant, informan dengan latar belakang yang mengikuti organisasi film Kine berada pada posisi negotiated, serta informan yang mengikuti organisasi Rohis berada pada posisi oppositional.
\end{abstract}

Copyright (C) 2019 Channel Jurnal Komunikasi. All right reserved. 


\section{PENDAHULUAN}

Dewasa ini seiring dengan berkembangnya teknologi, perkembangan media seakan semakin pesat dan tidak terkendali. Beberapa jenis media telah banyak yang muncul dengan tujuan untuk menyampaikan pesan kepada khalayak. Film telah menjadi salah satu media komunikasi massa yang efektif dalam penyebaran informasi serta menjadi salah satu bentuk karya yang disajikan dalam sebuah cerita berbentuk audio visual (Marliana, 2013).

Rushton dan Bettinson (dalam Lukmantoro, 2016) menyatakan bahwa bagaimana film itu bekerja, film mengirimkan makna, fungsi apa saja yang ditawarkan oleh film dan bagaimana film mempengaruhi kita sebagai penontonnya. Artinya, film memang dapat diuraikan dari berbagai aspek sesuai kebutuhan dan minat kita. Film dapat dilihat dari tiga ranah, yaitu produksi (bagaimana film diciptakan), presentasi (bagaimana realitas yang ditampilkan pada film), dan resepsi (bagaimana penafsiran khalayak terhadap film yang sudah ditonton).

Secara umum, film terbagi menjadi tiga jenis, yaitu; fiksi, eksperimental dan dokumenter. Film dokumenter adalah salah satu jenis atau genre dari sebuah film yang berisi dokumentasi dari suatu kejadian nyata. Selain itu, film dokumenter juga berisi mengenai subjektivitas dari si pembuat film itu sendiri (Trianton, 2013). Artinya, apa yang terekam memang berdasarkan kejadian nyata yang ada, selain itu dalam penyajiannya si pembuat film juga memasukan ide atau pikiran dan sudut pandang idealismenya. Penyajian yang utama dalam film dokumenter adalah penyajian yang berdasarkan fakta. Film dokumenter merekam suatu peristiwa atau kejadian yang benar-benar terjadi (Pratista, 2008)

Film dokumenter yang berjudul Bulu Mata merupakan salah satu film garapan Rumah Dokumenter Klaten yang di sutradarai oleh Tonny Trimarsanto. Film tersebut terpilih menjadi Film Dokumenter Terpanjang dalam ajang Piala Citra tahun 2017. Penghargaan tersebut merupakan penghargaan ketiga yang diraih film Bulu Mata. Sebelumnya, film Bulu Mata diputar dalam Festival Film Internasional di Kamboja dan Festival Film Yogyakarta. Film tersebut menceritakan bagaimana kehidupan para kaum minoritas khusunya transgender yang ada di Kabupaten Bireun, Aceh. Film Bulu Mata juga memperlihatkan bagaimana kehidupan mereka sehari-hari sebagai transgender dengan orang sekitar dan dengan keluarga mereka. Menariknya dalam film ini juga diceritakan bagaimana keluarga mereka bisa menerima keadaan para transgender tersebut. Penerimaan dari keluarga berdampak kuat pada citra diri dan jalan hidup yang ditempuh para transgender (Hartoyo dan Adinda, 2014). Dalam masyarakat, transgender masih sering diberi label sebagai kriminal dan meresahkan masyarakat. Penyamarataan pemikiran yang seperti itulah membuat daerah-daerah mengeluarkan peraturan yang cenderung diskriminasi. Film Bulu Mata diakhiri dengan diskusi para kelompok transgender yang membicarakan mengenai peraturan syariah Qanun Jinayah, Sebuah peraturan yang mendapat kecaman dari para aktivis HAM.

Transgender merupakan salah satu sikap yang dianggap menyimpang dari peran gender yang telah dikonstruksikan. Artinya seseorang yang mengidentifikasikan orientasi seksualnya secara gender berbeda dengan jenis kelamin secara biologis (Linda dalam Jasrudin dan Daud, 2016). Misalnya dengan transgender laki-laki, yang mempunyai kelamin normal layaknya laki-laki, namun secara psikis merasa dirinya ialah perempuan akibatnya perilaku keseharian mereka tampak kaku, fisiknya laki-laki tetapi dari cara berjalan, berbicara dan dilihat dari dandanan yang dipakai menyerupai perempuan (Barmawi dan Silmi, 2016). Transgender sangat berbeda dengan transeksual, yang mendasari perbedaan tersebut ialah transgender belum pasti transeksual, tetapi apabila transeksual sudah pasti transgender. Seseorang yang mengubah sifat dan sikap yang tidak sesuai dengan kodratnya belum tentu mengubah jenis kelaminnya (Jasrudin dan Daud, 2016).

Fenomena transgender di Indonesia merupakan bukan hal yang biasa, fenomena tersebut banyak menuai pro dan kontra. Pihak-pihak yang pro akan perilaku transgender beranggapan, bahwa orientasi seksual yang terdapat pada setiap individu merupakan Hak Asasi Manusia bagi mereka. mereka menyatakan, masyarakat harus adil dan menghilangkan prinsip diskriminasi terhadap kaum transgender, heteroseksual dan homoseksual (Santoso, 2016). Tetapi sebaliknya, pihak yang kontra terhadap perilaku transgender mereka menganggap bahwa transgender di Indonesia merupakan bentuk penyimpangan sosial dan tidak termasuk dalam rancangan HAM.

Seorang transgender tidak akan memperlihatkan bentuk spesifik dari orientasi seksualya. Mereka bisa saja mengidentifikasi dirinya sebagai homoseksual, heteroseksual, biseksual, atau aseksual. Adapun pemicu seseorang bisa menjadi transgender, diakibatkan oleh 2 faktor, yaitu faktor bawaan (hormon \& gen) dan faktor lingkungan. Diantara dua faktor tersebut, faktor lingkungan merupakan salah satu faktor terbesar yang mendasari seseorang menjadi transgender (Sari, 2016). Isu transgender merupakan isu yang sensitif terutama apabila menyangkut standar keyakinan religi masyarakat Indonesia, bahwa agama telah mengkonstruksikan mengenai jenis kelamin dan gender hanya ada dua, yaitu laki-laki dan perempuan (Hutomo, 2016)

Peneliti tertarik dengan film dokumenter Bulu Mata untuk penelitiannya karena film yang menceritakan tentang bagaimana kehidupan dan cara mereka bertahan hidup sebagai transgender di Aceh, dimana kita tahu Aceh merupakan daerah di Indonesia yang kental akan syariat islam dan jelas melarang pelaku transgender. Selain itu, peneliti juga bermaksud untuk mencari tahu pemaknaan khalayak terhadap perubahan identitas gender yang ada dalam film Bulu Mata.

Penelitian ini menggunakan teori Encoding-Decoding yang dikemukakan oleh Stuart Hall. Encoding yaitu bagaimana isi dari media itu di produksi sedangkang decoding adalah konsumsi atas isi dari suatu media. Pada penelitian ini membahas mengenai bagaimana audiens memaknai identitas transgender yang ditampilkan dalam film dokumenter 
Bulu Mata. Metode penelelitian ini menggunakan metode analisis resepsi dengan fokus mengenai bagaimana khalayak menginterpretasikan isi media tersebut (Baran dalam Hadi, 2009). Terdapat tiga hipotesis mengenai bagaimana khalayak memaknai pesan dari suatu media, pertama adalah dominant reading yakni khalayak sepenuhnya menerima pesan yang telah disampaikan oleh media. Kedua, negotiated reading yaitu khalayak menerima pesan kemudian di negosiasikan karena memiliki pandangan berbeda. Ketiga, oppositional reading yaitu khalayak sepenuhnya menolak pesan yang telah disampaikan dari media (Morley dalam Pujileksono, 2015)

Penelitian pertama dilakukan oleh Liyya Oktavia Nur Cahyani (Mahasiswi Jurusan Ilmu Komunikasi Fakultas Psikologi dan Ilmu Sosial Budaya) tahun 2017, berjudul Analisis Resepsi Informasi Kreatif dan Pengetahuan Lokal Dalam Film Dokumenter (Studi Kasus dalam Film Dokumenter “The First Impression”). Fokus penelitian ini yaitu bagaimana pemaknaan informasi kreatif dan pengetahuan lokal dalam film dokumenter. Metode analisis yang digunakan adalah analisis resepsi. Dengan pengambilan sampling menggunakan purposive sampling dan snowballing. Persamaan pada penelitian ini yaitu sama-sama meneliti menggunakan metode analisis resepsi. Sedangkan perbedaan pada penelitian ini terletak pada subjek penelitian.

Penelitian selanjutnya yang dilakukan oleh Fitri Meliya Sari pada tahun 2016, dengan judul "Konstruksi Media Terhadap Transgender". Fokus pada penelitian ini mencoba menjawab bagaimana media menggambarkan eksistensi transgender di Indonesia melalui media. Hasil penelitian menunjukan bahwa adanya pembenaran khusus media dalam menggambarkan secara negatif perilaku orang-orang yang menjadi transgender. Persamaan penelitian ini yaitu samasama meneliti mengenai transgender sebagai objek penelitian.

Berdasarkan pemaparan latar belakang masalah diatas, maka penelitian ini bertujuan untuk mengetahui bagaimana resepsi audiens terhadap transgender dalam film dokumenter yang berjudul Bulu Mata.

Identitas merupakan konsep mengenai diri kita. Identitas menjadi masalah kompleks mengenai bagaimana memahami dirinya sendiri. Stephen Littlejohn beranggapan bahwa diri kita memperoleh identitas bagian dari konstruksi yang menawarkan identitas tersebut dari berbagai kelompok sosial dimana kita menjadi bagian keluarga, masyarakat dan kelompok budaya. Artinya, identitas kita dalam proses pembentukan seiring dengan bagaimana kita merespons konteks dan situasi di sekeliling kita (Littlejohn dan Foss, 2012).

Stuart Hall mengemukakan bahwa identitas adalah suatu konstruksi yang lentur, sebuah proses yang bukan lagi hanya mengada-ngada tetapi menjadi perbedaan yang mendasari antara antara "kita ini siapa" dan "kita menjadi apa". Proses "becoming" akan terjadi secara terus menerus dan tergantung oleh keadaan sosial, budaya, ruang dan tempat (Rutherford, 1990). Identitas itu sendiri adalah masalah posisi yang berkaitan dengan konsep representasi, menurut Hall (1996) identitas juga tentang merepresentasikan diri. Identitas meliputi cara seseorang melihat dirinya sendiri dan bagaimana orang lain melihat orang itu (Stuart Hall dalam Sari, 2016). Identitas menjadi permasalahan ketika seseorang merasakan dirinya tak sesuai dengan apa yang terlihat. Oleh karena itu bagaimana seseorang mendefinisikan dirinya dan bagaimana orang lain mendefinisikannya dengan berbagai alasan, orang akan berkomunikasi dengan budaya lain dengan meningkatkan kepekaan interpersonal (Littlejohn \& Foss, 2012)

Konsep sebuah identitas yang diyakini mengenai diri kita bisa disebut dengan identitas-diri, sementara persepsi dari orang lain akan membentuk sebuah identitas sosial. Dalam teori, identitas bisa diartikan sebagai keseluruhan dari konstruksi sosial dan tidak bisa keluar dari konsep representasi kultural. Identitas mencakup bagaimana kita melihat diri kita sendiri dan bagaimana orang lain melihat diri kita. Untuk membedakan atau menyamakannya orang satu dengan orang yang lainnya bisa diposisikan sebagai sebuah "subjek" atau disebut dengan "genderred subject" (Barker, 2004).

Giddens (1991) berpendapat bahwa, identitas diri adalah pikiran tentang diri kita, apa yang kita pikirkan mengenai diri kita sebagai seorang manusia. Selain itu identitas juga bukanlah gabungan dari sifat-sifat yang kita miliki, tetapi identitas merupakan cara berfikir tentang diri kita. Maksudnya adalah, identitas diartikan sebagai sesuatu yang kita ciptakan sendiri. Sebuah identitas akan membentuk apa yang kita pikirkan mengenai diri kita sendiri dilihat dari sudut situasi masa lalu dan masa yang sekarang, bersamaan dengan apa yang kita pikirkan mengenai keinginan dan apa harapan kita kedepan. (Giddens dalam Barker, 2004).

Analisis resepsi merupakan salah satu pendekatan alternatif yang mempelajari mengenai studi khalayak, bagaimana memaknai pesan yang diterima dari isi media. Studi resepsi pertama kali dipopulerkan oleh Stuart Hall (1974) dengan teori Encoding-Decoding. Hall mengemukakan bahwa sebuah pesan yang masuk tidak lagi dipahami sebagai objek yang dikirim oleh sender kepada receiver. Pesan yang telah dikirim dan diterima tidak selalu sama, tiap-tiap kode yang dikirimkan akan dimaknai berbeda oleh masing-masing audiens (Hall dalam Alasuutari, 1999). Artinya, pengirim mengkodekan makna pesan sesuai dengan pandangan mereka dan pesan tersebut dapat ditafsirkan berbeda oleh penerima berdasarkan pandangan atau ideologi masing-masing (Hall dalam Haryanti dan Ratna Sari, 2018). Fokus lain dari analisis resepsi yaitu bagaimana khalayak dari latar belakang yang berbeda memaknai isi pesan dari media. Hal tersebut dikarenakan media memiliki banyak makna yang bisa diinterpretasikan oleh khalayak sesuai dengan sudut pandangnya masing-masing. Pesan yang disampaikan media bisa juga dimaknai secara berbeda oleh penerima yang berbeda pula. Maka dari itu makna yang diperoleh dari pembaca satu dengan pembaca yang lainnya tidak sama (Barker, 2004) 
Sebuah paradigma resepsi mengungkapkan bahwa pesan yang disampaikan oleh komunikator menggunakan rencana sebagai bahan dari media massa yang di dalamnya terdapat sebuah pesan dengan tujuan tertentu (Alasuutari, 1999). Suatu pesan apapun yang disampaikan oleh media, akan dimaknai oleh khalayak berdasarkan latar belakang budaya, sosial dan ekonomi yang berbeda dari masing-masing audiens. Isi dalam media diartikan sebagai bagian dari common sense yang di interpretasikan melalui pembacaan yang dari gambar dan teks bahasa. Sedangkan suatu makna teks dari media bukanlah sebuah fitur transparan, tetapi merupakan interpretasi dari pembaca dan penonton (Street dalam Hadi, 2009). Kasus pada studi analisis resepsi terdapat proses encoding-decoding, ada beberapa faktor yang mempengaruhi dalam proses pemaknaan, yaitu framework of knowledge, relations of production dan technical infrastructure (Hall dalam Alaasutari, 1999).

Hall (1974) berpendapat bahwa terdapat empat type posisi ideal dari decoding komunikasi massa oleh audiens yang dapat dilakukan: 1) dominant or hegemonic code (kode dominan atau hegemonik) yaitu tingkat konotatif dari sebuah pesan yang di-decode-kan secara dominan dalam makna yang disukai; 2) professional code (kode profesional) yaitu apa yang digunakan para penyiar profesional ketika mengirim pesan dan ditandai dengan cara hegemoni; 3) negotiated code (kode negosiasi) berisi campuran elemen oposisi dan adaptif; 4) oppositional code (kode oposisi) adalah dimana posisi pemirsa sangat memahami infleksi harfiah maupun konotatif yang telah diberikan pada suatu kejadian, tetapi memutuskan untuk memisahkan kode pesan dengan cara bertentangan dari cara yang umum (Alasuutari, 1999).

Sejalan dengan pemaparan diatas, implementasi dari teori dengan penelitian ini adalah untuk mengetahui pemaknaan khalayak mengenai film dokumenter Bulu Mata yang menampilkan identitas transgender. Audiens dapat mengkaji makna dengan sebagaimana mestinya, sehingga khalayak tidak hanya menjadi konsumen dari isi media tetapi juga produser dari isi media yang ditampilkan.

\section{METODE PENELITIAN}

Jenis penelitian ini adalah penelitian kualitatif yang bertujuan untuk memahami fenomena sosial yang ada. Penelitian kualitatif merupakan penelitian yang bersifat intrepretif yang akan dikaitkan dengan beberapa metode dalam membahas masalah penelitiannya (Mulyana, 2013). Pengumpulan data yang dilakukan pada penelitian ini menggunakan metode wawancara yang mendalam (indepth interview), dengan metode ini dalam mengumpulkan data, peneliti menggali informasi-informasi secara intensif. Dalam metode indepth interview mempunyai ciri khas yaitu keterlibatan dalam kehidupan informan (Bungin, 2007).

Reception analysis mengacu pada penggunaan suatu media sebagai alat representasi situasi sosial budaya dan juga sebagai proses terhadap makna yang diberikan khalayak berdasarkan pengalaman dan produksi yang diterima (McQuail dalam Hadi, 2009: 5). Morissan (2013) berpendapat bahwa, dalam proses pemaknaan pesan encoding dapat diartikan sebagai aktivitas yang dilakukan oleh sumber dalam mengartikan gagasan atau ide terhadap pesan yang diterima oleh indra penerima itu sendiri. Setiap orang akan melakukan proses encoding yang berbeda-beda. Sedangkan decoding diterjemahkan sebagai kemampuan khalayak dalam menerima atau membandingkan pesan dengan makna yang pernah terjadi, seperti pemikiran, persepsi bahkan pengalaman di masa lampau. Decoding lebih ditekankan pada proses yang meghasilkan makna kemudian dibagikan dengan orang lain, karena media telah melekat dengan kehidupan sosial manusia setiap harinya (Jensen dalam Hadi, 2009: 4).

Pada penelitian ini pengambilan sampel dilakukan dengan purposive sampling yaitu teknik pengambilan data berdasarkan dengan maksud atau tujuan tertentu yang telah ditentukan oleh peneliti. Penentuan informan sebagai sampel dianggap bisa memberikan informasi yang diperlukan untuk kepentingan penelitian (Pujileksono, 2016). Pemilihan informan memiliki persyaratan tertentu dan dirasa memiliki kemampuan untuk menjawab rumusan masalah yang yang diangkat dalam penelitian ini. Informan yang dipilih oleh peneliti memiliki persyaratan tertentu serta memiliki kemampuan menjawab dan memberi informasi guna menjawab fenomena atau masalah yang sedang di teliti. Fakor dalam menentukan informan didasarkan pada tiga kategorisasi, yakni framework of knowledge, relations of production, technical infrastructure (Hall dalam Alasuutari, 1999). Pada penelitian ini menggunakan subjek enam mahasiswa informan laki-laki dan perempuan. Pertama, informan A dan B mahasiswa yang tertarik dengan film dan juga tertarik mengenai isu gender. Kedua, informan $\mathrm{C}$ dan $\mathrm{D}$ mahasiswa penyuka film dan mengikuti organisasi Kine. Ketiga, informan $\mathrm{E}$ dan $\mathrm{F}$ mahasiswa yang tertarik dengan film dan mengikuti organisasi Rohis. Ketiga kriteria informan tersebut sangat berpengaruh dalam menentukan bagaimana khalayak memaknai pesan yang telah disampaikan oleh media. Objek pada penelitian ini yaitu film dokumenter Bulu Mata.

Berdasarkan kriteria diatas, peneliti merujuk pada reception analysis yang dikemukakan oleh Stuart Hall. Pada penelitian ini menggunakan teknik pengumpulan data dengan analisis resepsi berupa wawancara yang mendalam (indepth interview), dimana subjek penelitian mampu memberikan pemaknaan mereka yang berkaitan dengan fenomena yang sedang diteliti. Metode wawancara yang mendalam (indepth interview) dinilai sangat efektif karena mampu untuk mengetahui lebih luas dan mendalam mengenai bagaimana informan memaknai pesan dari media (decoding). Proses wawancara dari awal hingga akhir dilakukan perekaman audio record menggunakan ponsel. Hasil wawancara akan memperoleh informasi berupa kata atau teks yang kemudian menghasilkan suatu deskripsi atau gambaran dari 
permasalahan penelitian.

Validitas data pada penelitian ini menggunakan metode teknik validitas data dengan triangulasi sumber, yaitu mencocokkan dan memverifikasi data informasi yang diperoleh dari hasil wawancara dengan informan (Bungin, 2007). Data yang terdapat pada penelitian ini terbagi menjadi dua yaitu data primer dan data sekunder. Data primer yang berupa pendapat dan pemahaman dari informan yang diperoleh melalui wawancara dengan mengajukan pertanyaan sesuai dengan objek penelitian. Proses perekaman di setiap melakukan wawancara menggunakan recorder. Data sekunder di dapat melalui buku, jurnal dan internet. Analisis data pada penelitian ini menggunakan model Miles dan Huberman dilakukan dengan 3 tahap; Pertama, reduksi data dan menawarkan penjelasan mengenai informasi yang telah diberikan oleh informan ketika menjawab pertanyaan. Kedua, yakni pengkategorian data, pemindaian data berdasarkan kelompok yang sudah ditentukan supaya memudahkan dalam proses analisis. Ketiga, penyajian data yaitu menyusun data yang berupa rekaman audio menjadi uraian singkat berbentuk teks atau narasi yang kemudian dilanjutkan dengan penarikan kesimpulan. Analisis data pada penelitian kualitatif dilakukan saat pengumpulan data berlangsung dan sesudah pengumpulan data dalam rentang waktu tertentu. Analisis data dilakukan secara terus menerus dan bersifat interaktif sampai selesai dan datanya sudah jenuh (Pujileksono, 2016).

\title{
HASIL DAN PEMBAHASAN
}

Berdasarkan dari hasil wawancara oleh 6 orang informan, peneliti menemukan beberapa penemuan terkait dengan resepsi khalayak terhadap Transgender dalam film dokumenter Bulu Mata. Untuk membedakan informan dalam penelitian ini, disini terdapat informan dengan inisial A dan B digunakan untuk audiens yang tertarik dengan isu gender khususnya transgender. inisial C dan D yang mengikuti organisasi Kine. Sedangkan E dan F audiens yang mengikuti organisasi Rohis. Penelitian ini menggunakan analisis deskriptif kualitatif yang menggunakan teknik reduksi data dari Miles \& Huberman (Pujileksono, 2015).

\section{A. Resepsi terhadap Isu Transgender dalam Film Bulu Mata: Dominant Reading}

Pemaknaan khalayak dari setiap individu terhadap suatu pesan dipengaruhi oleh latar belakang pengalaman yang berbeda dan tidak selalu sama. Ketika sedang melakukan komunikasi dengan orang lain yang memiliki perbedaan latar belakang, akan memungkinkan terjadinya penerimaan makna pesan yang berbeda (Matsumoto \& Juang, dalam Asmara \& Kusuma: 137). Ada beberapa faktor yang memicu proses pemaknaan pesan bisa berbeda, yaitu adanya kerangka pengetahuan (framework of knowledges), relasi produksi (relation of production), dan infrastruktur teknis (technical infrastructure) (Hall dalam Alasuutari, 1999). Berdasarkan perbedaan latar belakang pemahaman dalam memaknai arti transgender itulah yang kemudian menjadikan peneliti ingin mengetahui bagaimana khalayak memaknai transgender dalam film dokumenter Bulu Mata. Reception Analysis yang digunakan dalam penelitian ini untuk mengetahui bagaimana pemaknaan khalayak mengenai suatu pesan yang dibentuk oleh media dengan latar belakang masing-masing.

Istilah transgender seringkali dianggap sebagai identitas yang memiliki gender diluar laki-laki dan perempuan secara natural. Dalam bukunya yang berjudul The 'O' Project karya Firliana Purwanti menjelaskan mengenai apa yang disebut transgender. Transgender ialah seseorang yang memakai akesoris atau atribut gender yang berbeda dengan konsepsi gender yang dikonstruksikan oleh masyarakat pada umumnya. pada kasus ini lebih mengarah ke sikap dan peran berbeda dari yang seharusnya sudah dikonstruksikan. (Sulhin dan Yudah, 2014).

\begin{abstract}
... bagus yaa mbak, sebenarnya dengan adanya film-film kaya gini tuh lebih mengedukasi sih, maksutnya orang-orang kaya gitu tuh ngga harus dijauhin, soalnya banyak orang-orang kaya mereka tuh bermanfaat buat lingkungannya (informan A, 20 tahun, tertarik dengan isu gender)
\end{abstract}

... yaa bagus sih, adanya film yang mengangkat isu transgender kita bisa ambil pesan moralnya. Kalo misal orang yang kaya gitu tuh di Indonesia ada dan kita harus menghargai, soalnya dia juga manusia kan, yaa saling menghargai aja sesama manusia. (informan B, 20 tahun, tertarik dengan isu gender)

Pendapat yang lain disampaikan oleh informan C berbeda dengan apa yang disampaikan informan A dan B. Menurutnya, yang menjadi menarik dari film dokumenter tersebut karena mengangkat isu transgender yang berada di provinsi yang sangat menjunjung tinggi syariat Islam. Seorang transgender yang hidup di wilayah tersebut selalu di bayang-bayangi ketakutan berlakunya Qanun Jinayah, hukum pidana yang telah diatur berdasarkan syariat (Pujaningrum \& Wicaksono, 2016)

... menurut saya cukup menarik ya, kita jadi tahu kalau transgender itu kehidupannya seperti apa, apalagi itu tadi dari latar dokumenter di kota Banda Aceh yang notabennya adalah kota dimana menjunjung tinggi syariat Islam, isu yang diangkat cukup menantang juga ya. (informan C, 23 tahun, audiens yang mengikuti organisasi Kine) 
Sama halnya dengan yang disampaikan informan C, informan D beranggapan bahwa film yang mengangkat isu transgender merupakan hal yang menarik untuk diangkat.

... menurut saya sih baik ya, karena ya itu tadi isu transgender di Indonesia sangat sensitif dan masyarakat banyak yang tidak setuju akan hal tersebut jadi saya cukup tertarik dan suka sih dengan isu yang diangkat. (Informan D, 23 tahun, mengikuti organisasi Kine)

Sama dengan yang diungkapkan oleh informan D, informan E dan F juga beranggapan bahwa masyarakat harus sadar akan keberadaan dari seorang transgender yang hidup di lingkungan berdampingan dengan kita.

... membuka kacamata masyarakat adanya keberadaan mereka (transgender) di masyarakat, bagaimana cara hidup dan gaya mereka. bagaimana mereka memerankan pribadi yang menurut mereka itu keperempuanan banget, laki-laki yang seperti perempuan banget meskipun itu didalam Islam sebenernya dilarang ya mbak, karena kan tidak sesuai dengan syariat Islam (informan E, 22 tahun, mengikuti organisasi Rohis)

... bagus aja sih, cukup baik untuk bisa memberikan pandangan kepada orang lain mengenai seorang transgender, mungkin pandangan orang lain terlalu diskriminatif atau gimana gitu mungkin dengan menonton film ini pandangan orang lain justru malah jadi beda. Cukup bagus sih, Setidaknya dengan adanya film seperti ini bisa memberikan banyak perspektif tentang transgender. (informan F, 23 tahun, mengikuti organisasi Rohis)

Beberapa masalah yang sering ditemui oleh seorang transgender adalah diskriminasi. Diskriminasi yang dilakukan bisa berupa diskriminasi verbal maupun non verbal sehingga mereka merasa dirinya terpinggirkan. Karena itu lah kaum transgender sering mendapatkan perlakuan deksriminatif bahkan sampai perlakuan yang tidak berkemanusiaan oleh masyarakat luas. Seorang transgender sering kali mendapat ejekan sejak ia merasa bahwa ada yang salah antara identitas dirinya dengan gender yang dimilikinya (Lestari, 2018).

Pandangan oleh setiap individu terhadap isu transgender dalam film dokumenter dimaknai berbededa-beda berdasarkan latar belakang mereka. analisis resepsi mempunyai fungsi untuk menginterpretasikan mengenai bagaimana pandangan audiens pada pesan yang telah dibangun media dengan latar belakang yang berbeda dari masing-masing audiens (Hall dalam Durham dan Kellner, 2006)

... kita liatnya di Aceh ya, ternyata di Aceh itu deskriminasinya masih tinggi banget ya terhadap transgender bahkan sampe ada yang disindir potong aja alat reproduksinya gitu. padahal kan di Undang-Undang pun ada kita tuh harus memanusiakan manusia gitu. tidak memandang mereka dari etnis sosial, warna kulit atau apapun kan nggak diterangin juga, kita memandang mereka dari gender mereka kan gak ada di UU. Sebenernya di film ini tuh yg mencibir mereka kan yg gendernya udah ada laki-laki atau perempuan gitu ya, padahal mereka tuh juga belum tentu lebih mulia dari si transgender ini." (Informan A, tertarik dengan isu gender)

... sang pembuat film ini mungkin ini menampilkan bagaimana kehidupan transgender dimana islamnya kuat, padahal itu sangat di tentang. Selain itu membuat orang lain bisa berfikir terbuka mengenai transgender tersebut. (Informan $C$, mengikuti organisasi Kine)

... sebenarnya dengan adanya film ini membuka kacamata masyarakat luas tentang adanya transgender, tetapi harus ada pendampingan khusus dalam arti bukan hanya menyoroti keberadaan mereka saja tetapi perlu adanya solusi sebagaimana keberadaan mereka itu bermanfaat, tidak menjadi percontohan yaa, bukan menjadi salah satu public juga untuk diikuti siapapun karena yang ada di masyarakat itu banyak sekali penyelewengan, perbuatan yang diawali dengan kaum Transgender ini jadinya perlu adanya pendampingan itu supaya hidup mereka terarah bukan seenaknya mereka, apa adanya terus sifat keperempuanannya melebihi batas. (Informan E, mengikuti organisasi Rohis)

Pujaningrum dan Wicaksono (2016) mengatakan bahwa adanya seorang transgender di Indonesia khususnya di Aceh masih dianggap sesuatu hal yang tabu bahkan menyimpang dari aturan. Sejatinya, normativitas yang ada hanya mengakui dua gender, laki-laki dan perempuan. Tidak ada gender lain sleain kedua identitas gender tersebut. Akan tetapi, transgender merupakan sebuah realitas yang tidak bisa ditolak keberadaannya dan senantiasa ada dalam sejarah kehidupan manusia. Seringkali pandangan masyarakat terhadap kaum Transgender dinilai negatif bahkan tidak mau bergaul dengan seorang transgender justru membuat hidup mereka semakin terpinggirkan. Dalam masyarakat kita masih menilai seorang transgender adalah sesuatu yang berbeda bahkan ada pula yang sampai ketakutakan ketika melihat seorang transgender. 
Berdasarkan pengamatan yang telah peneliti lakukan terhadap semua informan, masing-masing mengungkapkan pendapatnya mengenai transgender dalam sebuah film dokumenter. Khalayak menunjukan bahwa mereka menerima kode-kode pesan yang diberikan dari media, bahwa adanya film yang mengangkat isu transgender merupakan hal yang bisa mengedukasi dan memberi kesadaran kepada masyarakat bahwa transgender itu ada dan tidak untuk dijauhi. dalam posisi ini khalayak berkedudukan dalam posisi dominant reading.

\title{
B. Resepsi terhadap Perubahan Identitas Gender: Antara Dominant Reading, Negotiated Reading, dan Oppositional Reading
}

Transgender ialah seseorang yang merujuk secara biologis dirinya ialah laki-laki namun dalam kehidupan sosial masyarakatnya ia hidup dan berpenampilan layaknya perempuan, tetapi tidak menjalani operasi modifikasi genital. Kehadiran transgender merupakan proses panjang secara individual maupun secara sosial. Terlahirnya perilaku transgender tidak lepas dari proses atau dorongan dari dalam dirinya. Mereka menyadari bahwa terdapat perubahan fisik yang tidak sesuai dengan kondisi psikisnya (Jasrudin dan Daud, 2016). Munculnya identitas seseorang dimulai dari tingkah laku atau kebiasaan. Sifat, karakter, sikap, cara berbicara, bahasa tubuh bahkan bisa juga dari pakaian yang digunakan.

\begin{abstract}
... kalo pendapat ku mengenai laki-laki yg seperti wanita atau sebaliknya, yaa mungkin wajar-wajar kali ya mbak. Kalo dilihat dari masyarakat sih mungkin rada aneh tp kalo menurutku di era milenial ini udah nggak aneh sih, apalagi kan sekarang ada trend yang namanya androgini, jadi androgini tuh kan penampilan yang tidak sesuai gender atau alat kelaminnya. Soalnya sekarang kan banyak tuh trend fashion yang emang unisex jadi bisa dipake buat cewek sama cowok. Kalo diliat dari perspektif androgini yaa terserah sih, no matter what you wear yang penting dia nyaman apa yang dia pakai. (Informan A, tertarik dengan isu gender)

... setuju-setuju aja yaa itu hak mereka pilihan mereka. Dia mannya kaya gitu, dia nyaman nya kaya gitu yaudah justru dia malah jadi dirinya sendiri dengan seperti itu. Tapi kan balik lagi ya mbak itu semua pilihan hidup mereka. (Informan B, tertarik dengan isu gender)
\end{abstract}

Sebagai audiens yang sudah menonton film dokumenter Bulu Mata, sebelumnya mereka telah mempunyai gambaran identitas laki-laki pada umumnya. mereka telah diajarkan dan mengerti bahwa seks dan gender adalah sama, laki-laki yang maskulin dan wanita adalah feminim (Whittle, 2006). Mereka telah mengubah konsep sosial dengan kode gender yang alami, merah muda dianggap untuk perempuan dan biru untuk laki-laki. Akan tetapi di era sekarang ini, biru dianggap warna gadis dan merah muda dianggap warna anak laki-laki. Informan A dan B merupakan salah seorang yang tertarik dengan isu gender mengungkapkan bahwa perubahan identitas pada setiap individu merupakan hal yang biasa di era sekarang ini. Sudah bukan merupakan hal yang tabu lagi apabila seseorang merubah identitas dirinya menjadi transgender. Bahkan, di era milenial ini sudah berkembang lagi menjadi trend yang dinamakan androgini.

Androgini merupakah istilah dalam identitas gender, seseorang yang tidak termasuk dengan jelas dalam peranan gendernya, maskulin atau feminim. Seorang androgini adalah seseorang yang memiliki dua karakter, maskulin dan feminim. Androgini tidak hanya mengacu pada fisik seseorang, melainkan gaya berpakaian androgini style juga mulai digemari banyak orang.

Pendapat lain disampaikan oleh informan $\mathrm{C}$ dan $\mathrm{D}$, mereka mengungkapkan bahwa perubahan identitas pada seseorang merupakan hal yang biasa dan sebuah pilihan hidup mereka masing-masing.

... kalo menurut saya pribadi itu sebuah pilihan dalam hidup, setiap orang diperkenankan untuk memilih pilihan mereka masing-masing. Namun sebelum ada pilihan kita juga biasanya juga ada sesuatu untuk melandasi pilihan tersebut dan itu agama. Jadi kalo menurut saya itu kalo laki-laki yang berdandan seperti perempuan menurut saya kurang pantas. (Informan C, mengikuti organisasi Kine)

... bagi saya sih itu biasa aja yaa, itu pilihan hidup mereka, identitas diri mereka. kita sebagai manusia ya harus bisa menghormati pilihannya tidak bisa memaksakan kehendak, kalo kita gak suka yaudah tidak perlu membenci atau apapun. Biasa aja sih mbak, menghormati dan menerima penampilan seperti itu yang menjadi identitas mereka. (Informan D, mengikuti organisasi Kine)

... kalo saya pribadi sih lebih ke menyerahkan pribadi masing-masing yaa, jadi kan setiap orang punya pilihan sendiri-sendiri. Terserah mereka, kalo mereka memilih merubah identitasnya seperti itu yaa nggak masalah. (Informan D, mengikuti organisasi Kine)

Informan E dan F merupakan informan yang mengikuti organisasi Rohis mengatakan bahwa perubahan identitas gender yang dilakukan oleh individu adalah suatu hal yang tidak dibenarkan atau tidak pantas karena tidak sesuai dengan 
syariat agama Islam yang berlaku.

... sangat tidak setuju. Jadi memang adanya waria itu realitas sosial itu sudah tidak bisa dipungkiri lagi mau dari Aceh, Jawa atau Kalimantan dan bahkan di luar negeri sekalipun ada, Transgender itu ada. Tetapi saya pribadi kurang sependapat, alangkah lebih baiknya mereka menyadari adanya Tuhan, mereka itu diciptakan oleh siapa dan mereaka bisa taat oleh ajaran mereka. apabila mereka muslim ya beribadah dengan sepantasnya, kalo laki-laki ya beribadah sesuai dengan laki-laki menggunakan peci menggunakan sarung, kalau perempuan ya berpakaianlah selayaknya perempuan berdandan tidak berlebihan, sewajarnya perempuan tidak ada yg kelewat batas. (Informan E, mengikuti organisasi Rohis)

... kalo menurut saya sih nggak setuju yaa, tidak di benarkan. kalo kita melihat dari kacamata agama ya khususnya agama islam, berperilaku laki-laki seperti perempuan atau sebaliknya itu tidak boleh atau dilarang. Tidak hanya berperilaku, bahkan di agama kita pun diajarkan berpakaian pun harus sesuai dengan porsinya, kalo perempuan menggunakan hijab kalo laki-laki yaa menutup auratnya. Intinya ada ketentuannya lah (Informan F, mengikuti organisasi Rohis)

Keenam informan diatas mengungkapkan bahwa terdapat beberapa pemaknaan yang berbeda. Informan A dan B masuk dalam kategori dominant hegemonic reading, mereka paham dan setuju bahwa perubahan identitas gender yang dilakukan oleh seseorang merupakan hal yang biasa dan tidak ada kesalahan atau menyalahi aturan. Kemudian, informan $\mathrm{C}$ dan $\mathrm{D}$ termasuk dalam kategori negotiated reading, dimana posisi khalayak menerima pesan kemudian dinegosiasikan, tidak selalu diterima begitu saja. Informan E dan F tergolong dalam kateogori oppositional reading, yakni khalayak tidak sepakat dan menolak dengan adanya perubahan identitas gender yang dilakukan dan memilih frame alternatif dalam memaknai pesan (Morley dalam Pujileksono, 2015).

\section{PENUTUP}

Hasil dari penelitian diatas, peneliti mengkategorisasikan hasil wawancara yang mendalam (indepth interview) terhadap enam informan kedalam dua kategori pembahasan; pertama, resepsi terhadap isu trasngender dalam film dokumenter Bulu Mata. Kedua, resepsi terhadap perubahan identitas gender dalam film dokumenter Bulu Mata.

Dari hasil wawancara diatas menunjukkan resepsi khalayak dalam memaknai isu transgender pada film dokumenter Bulu Mata sangat berbeda-beda. Menurut informan A dan B yang tertarik mengenai isu gender, film dokumenter Bulu Mata menampilkan gambaran kehidupan seorang transgender dan mereka menilai dengan adanya film yang mengangkat isu trasngender justru bisa mengedukasi masyarakat bahwa kita harus menghargai keberadaan mereka. selain itu, mereka juga mengungkapkan bahwa perubahan identitas gender yang dilakukan dalam film tersebut merupakan suatu hal yang wajar dan di era milenial ini justru didukung dengan trend yang namanya androgini, informan A dan B termasuk berada pada posisi dominant reading. Informan $\mathrm{C}$ dan $\mathrm{D}$ sebagai informan yang mengikuti organisasi Kine mengungkapkan bahwa film dokumenter Bulu Mata dengan isu yang diambil mengenai transgender, mereka mengungkapkan dengan adanya film tersebut cukup menarik dan menantang sehingga kita akan tahu bagaimana kehidupan transgender seperti apa. Selain itu, mereka juga mengungkapkan dengan perubahan identitas gender yang dilakukan oleh para transgender yang ada di film dokumenter Bulu Mata, merupakan sebuah pilihan hidup yang telah dipilih dari seorang transgender itu sendiri. Kita tidak serta merta harus memaksakan kehendak mereka meskipun sudah merubah identitas gendernya dan menjadi transgender merupakan hal yang kurang pantas, informan $\mathrm{C}$ dan D berada pada posisi negotiated reading. Informan E dan F sebagai salah seorang informan yang mengikuti organisasi Rohis yang mengerti sebagaimana syariat Islam berlaku, mereka mengatakan bahwa film yang mengangkat isu transgender bisa memberikan perspektif yang berbeda kepada orang lain dan membuka kacamata masyarakat supaya lebih sadar dengan keberadaan seorang transgender. Akan tetapi, mereka tidak setuju dengan seseorang yang merubah identitas dari gender aslinya, mereka menolak apabila terdapat seseorang yang menjadi transgender karena tidak sesuai dengan syariat Islam yang berlaku. Dalam agama Islam tidak dibenarkan laki-laki yang berpenampilan atau berperilaku seperti wanita, seharusnya laki-laki menjadi pemimpin bukan menjadi sosok perempuan, informan $\mathrm{E}$ dan $\mathrm{F}$ termasuk dalam posisi oppositional reading.

Film dokumenter Bulu Mata yang mengangkat isu mengenai bagaimana kehidupan nyata para transgender yang berada di Aceh menjadikan interpretasi khalayak terhadap transgender berbeda karena terdapat beberapa faktor latar belakang dan pengalaman dari setiap informan. Terlepas dari konstruksi atas media massa mengenai transgender yang ada pada film dokumenter Bulu Mata. Saran dari peneliti untuk penelitian berikutnya yang memiliki ketertarikan untuk membahas tema yang serupa yakni dengan membedakan subjek maupun objek penelitian guna keberagaman dan kedalaman data sehingga nantinya penelitian selanjutnya dapat komprehensif. 


\section{DAFTAR PUSTAKA}

Alasuutari, P. (1999). Rethinking The Media Audience. (P. Alasuutari, Ed.). SAGE Publications.

Asmara, L. R., \& Kusuma, R. (2016). Pria Barat Menurut Pandangan Khalayak Indonesia (Studi Pandangan Khalayak Indonesia Tentang Sosok Pria Barat Ideal Melalui Karakter Fiksi dalam Film Drama Romantis Hollywood). The $4^{\text {th }}$ University Research Coloqium. ISSN 2407-9189.

Barker, C. (2004). Cultural Studies: Teori dan Praktek. Yogyakarta: Kreasi Wacana.

Barmawi \& Silmi, M. (2016). Identifikasi Penyebab Transgender Pada Waria di Banda Aceh. Psikoislamedia, Vol 1, No. 2, 372-373.

Bungin, B. (2007). Penelitian Kualitatif; Komunikasi, Ekonomi, Kebijakan Publik dan Ilmu Sosial Lainnya. Prenada Media Group.

Durham, Meenakshi Gigi; Kellner, Douglas M. 2006. Media and Cultural Studies. London. Blackwell Publishing.

Hadi, I. P. (2009). Penelitian Khalayak Dalam Perspektif Reception Analysis. Scriptura, (1-7).

Hartoyo, Adinda, T., Sabarini, P., Said, N, T., \& Bayu, G. (2014). Sesuai Kata Hati Kisah Perjuangan 7 Waria. Jakarta: Rehal Pustaka

Haryanti, Astrid. \& Siti Dewi Sri Ratna Sari. (2018). Analysis of Audince Reception on Youtube Towards Anti Cyberbullying Video Campaign in The Cyberbully by Cameoproject. Jakarta: Bina Nusantara University. SEEIJ (Social Economics and Ecolog International Journal), 2(1), Mar 2018, 57-63.

Jasrudin, \& Daud, J.(2016). Transgender Dalam Persepsi Masyarakat. Jurnal Equilibrium. Vol. II, No. 1, $20-22$.

Littlejohn, S. W \& Foss K. A. (2012). Theories of Human Communication. Jakarta: Penerbit Salmeba Humanika.

Lestari, Y. (2018). Representasi Identitas Diri Transgender Dalam Film Bulu Mata. Jakarta: UIN Syarif Hidayatullah.

Lukmantoro, \& Hutomo H, dkk. (2016). Teori-Teori Film: Sekedar Pengantar Awal dalam Junaedi, Fajar [ed] (2016). Menikmati Budaya Layar, Membaca Film. Yogyakarta: UMY, ASPIKOM, Buku Litera.

Marliana Dwi, S. (2013). Identitas Seksualitas Remaja Dalam Film. KomuniTi, Vol. V, No.2, 82-84.

Morissan. (2013). Teori Komunikasi Individu Hingga Massa. Jakarta: Kencana Prenada Media Group.

Mulyana, D. (2013). Metode Penelitian Komunikasi. Bandung: Remaja Rosdakarya.

Nugroho, F. (2007). Cara Pinter Bikin Film Dokumenter. Yogyakarta: Indonesia Cerdas.

Pratista, H. (2008). Memahami Film. Yogyakarta: Homerian Pustaka.

Pujileksono, S. (2015). Metode Penelitian Komunikasi Kualitatif. Jawa Timur: Intrans Publishing.

Pujaningrum, D. R \& Wicaksono B. (2016). Analisis Cerita Perjuangan Hidup Waria Dalam Film Dokumenter Bulu Mata, 1-2.

Purwanti, F. (2010). The 'O’ Project. Jakarta: Kepustakaan Populer Gramedia

Rutherford, J. (1990). Identity: Community, Culture, Difference. London: Lawrence and Wishart.

Santoso, M. B. (2016). LGBT Dalam Perspektif Hak Asasi Manusia. Kerta Patrika. Vol 6, No. 2, $221-222$.

Sari F. M. (2016). Konstruksi Media terhadap transgender. Jurnal Profesional. Vol. 3, No. 1, 23-29.

Toni, Ahmad \& Fajariko, Dwi. (2017). Studi Resepsi Mahasiswa Broadcasting Universitas Mercu Buana Pada Film Journalism "Kill The Messenger”. Jurnal Komunikasi. Vol. 9, No. 2, 151-155.

Trianton, Teguh. (2013). Film Sebagai Media Belajar. Yogyakarta: Graha Ilmu Publishing.

Whittle, S. S. (2006). The Transgender Studies Reader. New York: Routledge.

Yudah, Anindita Ayu Pradipta \& Sulhin, Iqrak. (2014). Representasi Transgender dan Transeksual dalam Pemberitaan di Media Massa: Analisis Wacana Kritis. Jakarta: Universitas Indonesia. 
